Received 12.03.2016 Reviewed 01.04.2016 Accepted 16.08.2016

A - study design

B - data collection

C - statistical analysis

D - data interpretation

E - manuscript preparation

F - literature search

\section{Changes in water quality of a small urban river triggered by deep drainage of a construction site}

\author{
${ }^{1)}$ University of Lodz, Department of Hydrology and Water Management, Narutowicza 88, 90-139 Łódź; \\ e-mail: adam.bartnik@geo.uni.lodz.pl \\ 2) Regional Inspectorate of Environmental Protection in Łódź, Lipowa 16, 90-743 Łódź; e-mail: p.moniewski@wios.lodz.pl
}

For citation: Bartnik A., Moniewski P. 2016. Changes in water quality of a small urban river triggered by deep drainage of a construction site. Journal of Water and Land Development. No. 31 p. 11-22. DOI: 10.1515/jwld-2016-0032

\begin{abstract}
The paper presents the results of the monitoring of the selected physicochemical properties of the Jasien River waters (in Łódź, the third biggest city of Poland) and their changes under the influence of drainage of a railway station Łódź Fabryczna construction site. Even 25 years ago the Jasień River was a receiver for the sewage from the Łódź textile factories. The drainage of the excavations and disposal of the water into the Jasień River was started on January 2014 and changed stable hydrological, physical and chemical regime of the river once again. In a consequence, average monthly flows exceeded the Jasien River flow in its upper section by six times, and at the beginning by even ten times. Chloride concentration was systematically growing over the study period. This growth and higher water $\mathrm{pH}$ were probably associated with increasing level of contaminants in the discharged water and its gradually decreasing uptake. Average annual water temperature increased and a decrease in its amplitude was observed. The annual conductivity and $\mathrm{pH}$ patterns became more uniform and the changes in $\mathrm{pH}$ followed a clear trend of monthly changes. Water turbidity increased by two times and during summer floods this parameter was often even a few times higher than before the drainage commenced. Chlorides improved water conductance and sodium and potassium increased basicity.
\end{abstract}

Key words: environmental impact, stormwater quality, rehabilitation, urban development, urban hydrology, water quality

\section{INTRODUCTION}

Functions of urban rivers have evolved over centuries. First, the rivers served as water source satisfying the needs of humans settling in river valleys. The power of flowing water was used to move mill devices. Later on, development of industry and particularly the invention of the steam engine and electricity have slowly changed the role of rivers and reduced them to receiving waters for sewage and storm water. Nowadays, increasing attention is paid to the quality and quantity of surface waters in urban areas. Urban rivers are no longer receiving waters for municipal sewage but they are still an integral element of a sew- erage network collecting storm water. They are also used as the receivers of water from draining pits or construction excavations [POWERS et al. 2007]. The water drained from the construction excavations is sometimes of better quality than that of the receiving river. Therefore, it reduces river contamination and improves the rate of self-purification in highly degraded rivers [CASHMAN, PREENE 2013; YE et al. 2012; YU et al. 2011]. The water quality condition and response in the river can be an immediate yardstick for base lining river water quality, and a basis for water quality modeling studies in the region [VISHNURADHAN et al. 2015].

The problem of the impact of the drainage of various investment on the environment is known and 
has already been discussed [QIN et al. 2014; TULARAM, DOBOS 2005]. Also the subsurface highway construction is associated with significant impacts on the urban groundwater system. Such a case is described e.a. in the EPTING et al. [2008] paper. The accurate prediction of environmental changes could be helpful to establish the solutions and minimize the damage level of environment [YE et al. 2012]. At present, the researches about prediction of environment changes caused by foundation pit dewatering are insufficient, and most of them are qualitative assessment. However, any of publication known to the authors was discussing issues of water quality changes of degenerated river under the influence of water coming from disposal of the good quality water from the excavations drilled with a grout curtain.

The aim of the research was to study to what extend the drained water from the construction place affect the small urban river regime. Changes in the water quality of the Jasien River results from deep drainage of groundwater. The water quality study on the Łódź Fabryczna railway construction place have started in February 2014. Preliminary results were published in an earlier study [BARTNIK, MONIEWSKI 2015]. However, it did not include a simultaneous analysis of physical and chemical features of water. This analysis based on high temporal resolution data acquired froms the multi-parametric probe, and was limited to the changes of a seasonal nature. Furthermore, it is important question if observed changes are constant or the hydrochemical regime of this river will come back to its previous state once the drainage is finished.

\section{RESEARCH AREA}

In the recent years, Łódź has invested heavily in communication and transportation facilities. One of the largest projects is a reconstruction of a railway station Łódź Fabryczna by transforming it into an underground station and building an underground tunnel in the the Jasien River basin. The entire course of the Jasień River $(13 \mathrm{~km})$ is located within the administrative borders of Łodź, a city in the central Poland (Fig. 1). Its catchment area at the mouth is $79.8 \mathrm{~km}^{2}$. Apart from anthropogenic layer (ca. $2 \mathrm{~m}$ deep), the surface sediments are dominated by glacioaqueous sands and outwash tills of the Wolstonian Stage. Due to a considerable height difference within the catchment area $(103 \mathrm{~m})$, the slope of the Jasien River is as high as in many mountain watercourses (5.6\%o). Its average annual flow before drainage at the point of entering the Ner River was $0.423 \mathrm{~m}^{3} \cdot \mathrm{s}^{-1}$, and average unit runoff from its catchment area was $5.3 \mathrm{dm}^{3} \cdot \mathrm{km}^{-2} \cdot \mathrm{s}^{-1}$.

Upper part of the catchment from the source to the probe covered the topographical area of $8.34 \mathrm{~km}^{2}$. Upstream of the main measurement point (no. 2), there are a $2 \mathrm{~km}$ long fragment of covered riverbed and 3 reservoirs. The first reservoir with an area of 1.0 ha and the capacity of $8500 \mathrm{~m}^{3}$ is supplied from a side weir only during rainfall with estimated probability of exceedance $10 \%$ and its lift height may increase by $0.5 \mathrm{~m}$. The second reservoir is a flowthrough one with an area of 1.2 ha and the capacity of $15500 \mathrm{~m}^{3}$. The third and the largest reservoir covers the area of 3.46 ha and its capacity is $75000 \mathrm{~m}^{3}$. With these numbers in mind, it may be assumed that total capacity of the reservoirs and the connecting riverbed is about $100000 \mathrm{~m}^{3}$. For most of the automatic recording period the largest reservoir was empty and ready was accepting possibly large amount of water that could reach the Jasien River valley as a result of discharging increased amount of water from the construction site drainage. This situation, however, did not occur, and a shallow reservoir was spontaneously formed filling the cavity created after dredging.

The Jasien has played an important role in Łódź history. Since the late Middle Ages its water was used to power water wheels of the mills located along its banks. The use of its water for energy generation became even more important at the times of intense industrial development. The greatest cotton factories of K. Scheibler, T. and L. Grohman or L. Geyer were created and flourished at the river banks, and the city was quickly growing in the valley. The riverbed was repeatedly changed, dams and reservoirs were built. Introduction of steam engines limited the use of the Jasien River water for energy generation and due to its deteriorating quality new intakes of groundwater in the valley were established. Since the turn of 19th and 20th century, the degraded river was in fact just a sewage receiver. The situation was not improved even when a sewerage system was built in the 1930s. The Jasien River, together with a few other urban rivers, was made a receiver water for the sewage from a combined sewage system. Its bed was regulated, deepened and reinforced. The primary objective was a quick removal of the sewage from the city, while completely overlooking natural functions of the watercourse. Today, there are still a few storm water overflows in the Jasien River catchment that during intense rainfalls discharge the excess waste water from the city center not equipped with a separate sewage system directly into the river.

Intensification of textile production in 20th century occurred at a huge cost to the environment. During the IIWW, a factory producing synthetic fibers (later "Chemitex-Anilana") was built in the upper catchment of the Jasien River, followed by a facility dealing with a disposal of toxic waste generated during the fiber production and discharging it into a special canal entering the Ner River ("Korchem"). Only at the end of the 20th century, together with closing almost all industrial units, the situation started to improve. Liquidation of textile industry and development of other more environmentally friendly sectors limited water demand and reduced wastewater generation by nearly $60 \%$. Despite that, the Jasień River was classified as "heavily modified water bodies", its condition was assessed as poor and the achievement of 


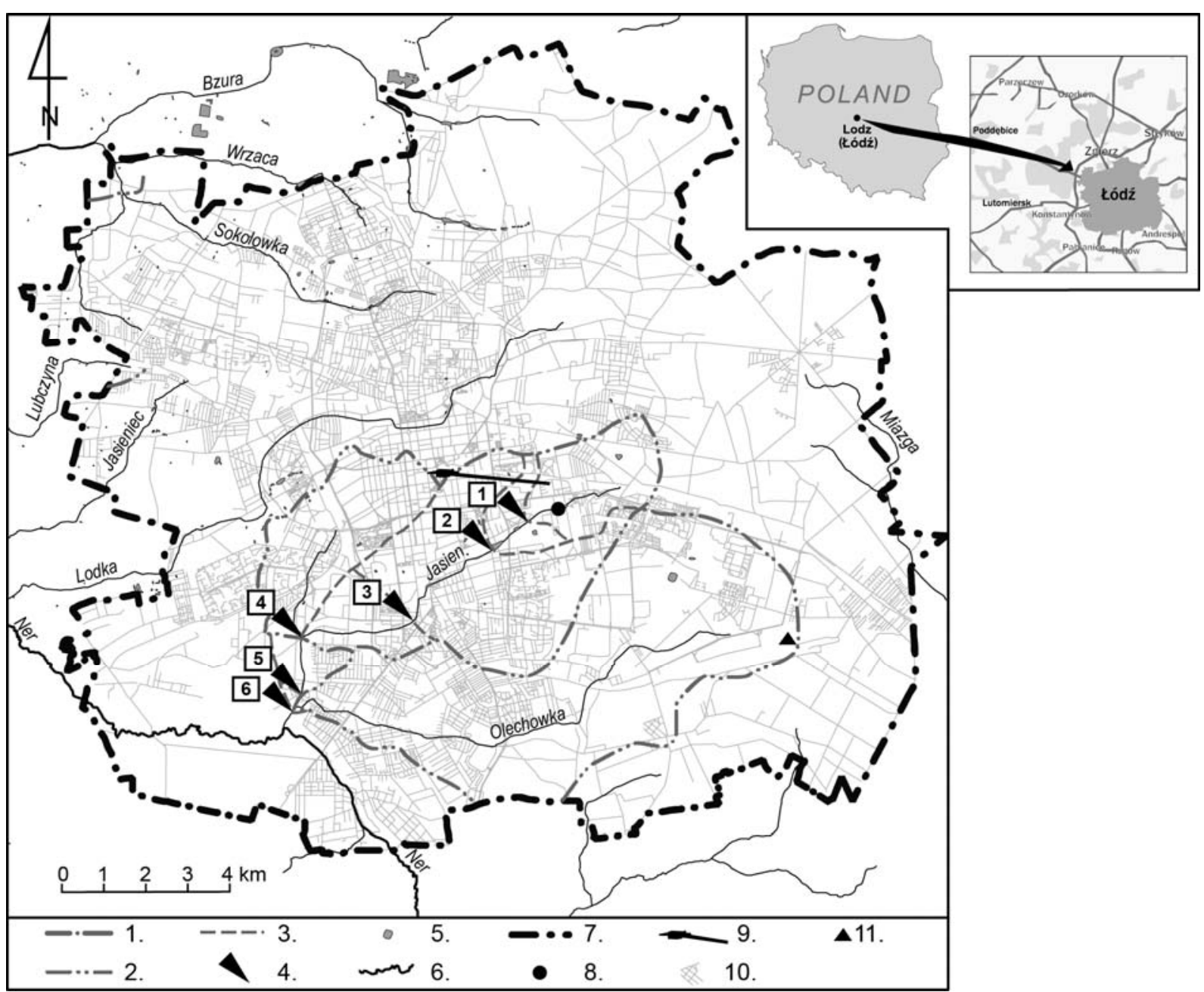

Fig. 1. The quality monitoring points at the Jasien River watercourse and the outlet of water discharge from the railway station Łódź Fabryczna construction site. Watershed according of its order: 1 - national divide, 2 - further orders;

3 - supplementary watersheds; 4 - measurement points ( 1 - Park, 2 - Przędzalniana Str., 3 - Piękna Str.,

4 - Laskowicka Str., 5 -Dubois Str., 6 -Odrzańska Str.); 5 -ponds; 6 -rivers; 7 - city borders; 8 - the outlet of water discharge from the construction site; 9 - the railway station Łódź Fabryczna construction site; 10 - roads; 11 - PKP Cargo meteorological station; source: own elaboration

environmental objectives was postponed until 2027 due to limited financial and technological resources. Over one third of the river still flows in a covered canal.

Significant changes in the environment of the basin were caused by construction of the underground Łódź Fabryczna railway station. During preparation of the construction site a large groundwater lens was encountered and bypassing it was not possible. Carrying on the works required drainage of the excavations and disposal of the water into the Jasien River, one of numerous urban watercourses. According to the provisions of the project a series of boreholes were performed, including eight piezometers and a well borehole, all of them constituting a system of observation wells. Water collected there is discharged into a storm water drain and then into the covered section of the Jasień River. The project assumed water withdrawal at the level of $2000 \mathrm{~m}^{3} \cdot \mathrm{h}^{-1}$. To reduce this amount discharged into the sewerage network and to limit the cone of depression, a grout curtain was drilled. Its aim was to reduce the amount of water to be discharged from the excavation to the maximum amount allowed by Municipal Water and Sewerage Company, i.e. 540 $\mathrm{m}^{3} \cdot \mathrm{h}^{-1}$. However, as indicated by data from an ongoing monitoring, lowering of the groundwater table was accompanied by discharging even four times as much water into the Jasien River. When the groundwater table was stable, water disposal was at the level of $1000 \mathrm{~m}^{3} \cdot \mathrm{h}^{-1}$ (ca. $0.25 \mathrm{~m}^{3} \cdot \mathrm{s}^{-1}$ ).

Permanent drainage of the excavation was started on January 15, 2014 and is to be continued until completion of the construction works (planned end: September 2016). The amount of water discharged into the Jasien River exceeds its mean flow in point 2 (ca. $0.044 \mathrm{~m}^{3} \cdot \mathrm{s}^{-1}$ ) by many times. As determined by the Regional Inspectorate of Environmental Protection (WIOŚ), the water pumped off the excavation comes from quaternary aquifer and is of good quality. WIOŚ reports for the years 2010-2013 indicated that 
the groundwater of the quaternary aquifer in the city of Łódź was good and very good quality [WIOŚ 2010-2013]. Considering the fact that the water of the Jasien River is highly polluted (high concentrations of ammonia, Kjeldahl nitrogen, $\mathrm{BOD}_{5}$ and $\mathrm{TOC}$ ), an improvement of its quality was expected after the excavation drainage was started. This expectation was reinforced by preliminary assessment classifying the water in the system of the observation wells into the second quality class based only on elevated content of sulphates $\left(240 \mathrm{mg} \cdot \mathrm{dm}^{-3}\right)$ and polycyclic aromatic hydrocarbons $\left(<0.002 \mathrm{mg} \cdot \mathrm{dm}^{-3}\right)$.

\section{MATERIALS AND METHODS}

The Jasień River has a long history of monitoring physical and chemical parameters of its water. Observation series for various measurement points are short. At the mouth of the river, there is a periodically operating gauging section of the Regional Inspectorate of Environmental Protection in Łódź (point 6), where water quality was monitored every month e.g. in the years 1974-1988 and 1993-2011. The effect of changes in the Jasien River valley use is reflected in the quality of its water (Tab. 1). In the years 19932011 mean water temperature decreased by almost $4^{\circ} \mathrm{C}, \mathrm{BOD}_{5}$ was 12 times lower, and the amount of suspended solids nearly 3 times lower compared to the period before the onset of the economic changes. Water quality analysis revealed also a general $6 \%$ decrease in the amount of substances dissolved in water, including $16 \%$ drop in sulphates and $38 \%$ drop in chlorides.

Further measurements (February 2012 - March 2013) were conducted by the Department of Hydrology and Water Management of the University of Lodz [DOBRZYŃSKA 2013]. They involved the watercourse quality monitoring every two weeks at four points (no.: 1, 3, 4 and 5). They allowed for initial assessment of hydrochemical condition of the Jasien River water and preceded its continuous monitoring that commenced at the beginning of discharging the water from the railway construction site drainage into the river. In January 2014, a multiparameter YSI probe, model 6920 V2 [YSI undated] was installed in the riverbed. The point of automatic measurement was located downstream of point 2 , at $8^{\text {th }} \mathrm{km}$ of the river course. The data used in analyses were taken from the probe equipped with a set of sensors for measuring temperature, conductivity, $\mathrm{pH}$, turbidity, dissolved oxygen, chloride, and ammonium concentration. The parameters were recorded for a 15-minute time step. $\mathrm{pH}$ sensor of the probe was damaged in early October 2014 but the recordings were continued for the other parameters. At the end of the monitoring period the turbidity sensor also failed to work.

Table 1. The archive average water quality characteristics of the Jasień River (measuring point no. 6) in the years 1974-1988 and 1993-2011

\begin{tabular}{|c|c|c|c|c|c|c|c|}
\hline Years & $\begin{array}{c}\text { Temperature } \\
{ }^{\circ} \mathrm{C}\end{array}$ & $\mathrm{pH}$ & $\begin{array}{c}\mathrm{BOD} \\
\mathrm{mg} \mathrm{O}_{2} \cdot \mathrm{dm}^{-3}\end{array}$ & $\begin{array}{c}\text { Suspended load } \\
\mathrm{mg} \cdot \mathrm{dm}^{-3}\end{array}$ & $\begin{array}{c}\text { Dissolved substance } \\
\mathrm{mg} \cdot \mathrm{dm}^{-3}\end{array}$ & $\begin{array}{c}\text { Chloride } \\
\mathrm{mg} \mathrm{Cl}^{-} \cdot \mathrm{dm}^{-3}\end{array}$ & $\begin{array}{c}\text { Sulphate } \\
\mathrm{mg} \mathrm{SO}_{4}^{2-} \cdot \mathrm{dm}^{-3}\end{array}$ \\
\hline $1974-1988$ & 16.0 & 7.50 & 130.5 & 132 & 619 & 133.0 & 119.0 \\
\hline $1993-2011$ & 12.2 & 7.50 & 10.6 & 49 & 584 & 83.0 & 100.0 \\
\hline
\end{tabular}

Source: Regional Inspectorate for Environmental Protection in Łódź (WIOŚ).

Both precipitation and temperature data were obtained from PKP Cargo meteorological station. In the first step the monitoring results were compared with previous observations and data on the amount of water pumped out of the construction site. However, due to the fact that the monitoring measurements were of patrol character and were taken every two weeks, the results gathered by the probe were downsampled. Thus, the comparative analysis took into account only the measurements recorded at the time similar to earlier patrol measurements (11-12) every two weeks.

The second part of the study included an analysis of synchronicity of the absolute physical and chemical parameters recorded by YSI probe at the point 2 in the period of discharging water from the construction site. Particular attention was paid to dayto-day changes in the parameter values. Another investigated issue were the changes in short-term physical and chemical characteristics of water recorded by the probe during different hydrological and meteorological events (three types of flood) between February 2014 and March 2015.

\section{RESULTS AND DISCUSSION}

Physical and chemical parameters of water in the period preceding the drainage (February 2012-March 2013) were characterized by high spatial and temporal variability. Average water temperature increased along the course of the river (Fig. 2A). The amplitude of its annual fluctuations rose as well. At the most upstream section (point 1), average water temperature was $10.7^{\circ} \mathrm{C}$, while at the next section at the end of the covered canal (point 3) it was $11.4^{\circ} \mathrm{C}$. Maximum temperature in the upper section was recorded in $\mathrm{Au}-$ gust $\left(15.4^{\circ} \mathrm{C}\right)$, and in the lower section in July $\left(9.2^{\circ} \mathrm{C}\right)$. Minimum temperature for both sections was reported in January and it was 6.2 and $3.9^{\circ} \mathrm{C}$, respectively. This suggested that the usually higher and more variable temperature depended on the surface of the ponds exposed to weather conditions and the supply of rain water running in the summer off the heated streets drained into the Jasień River.

Higher conductivity at all points was observed in the winter as a result of receiving water contaminated 

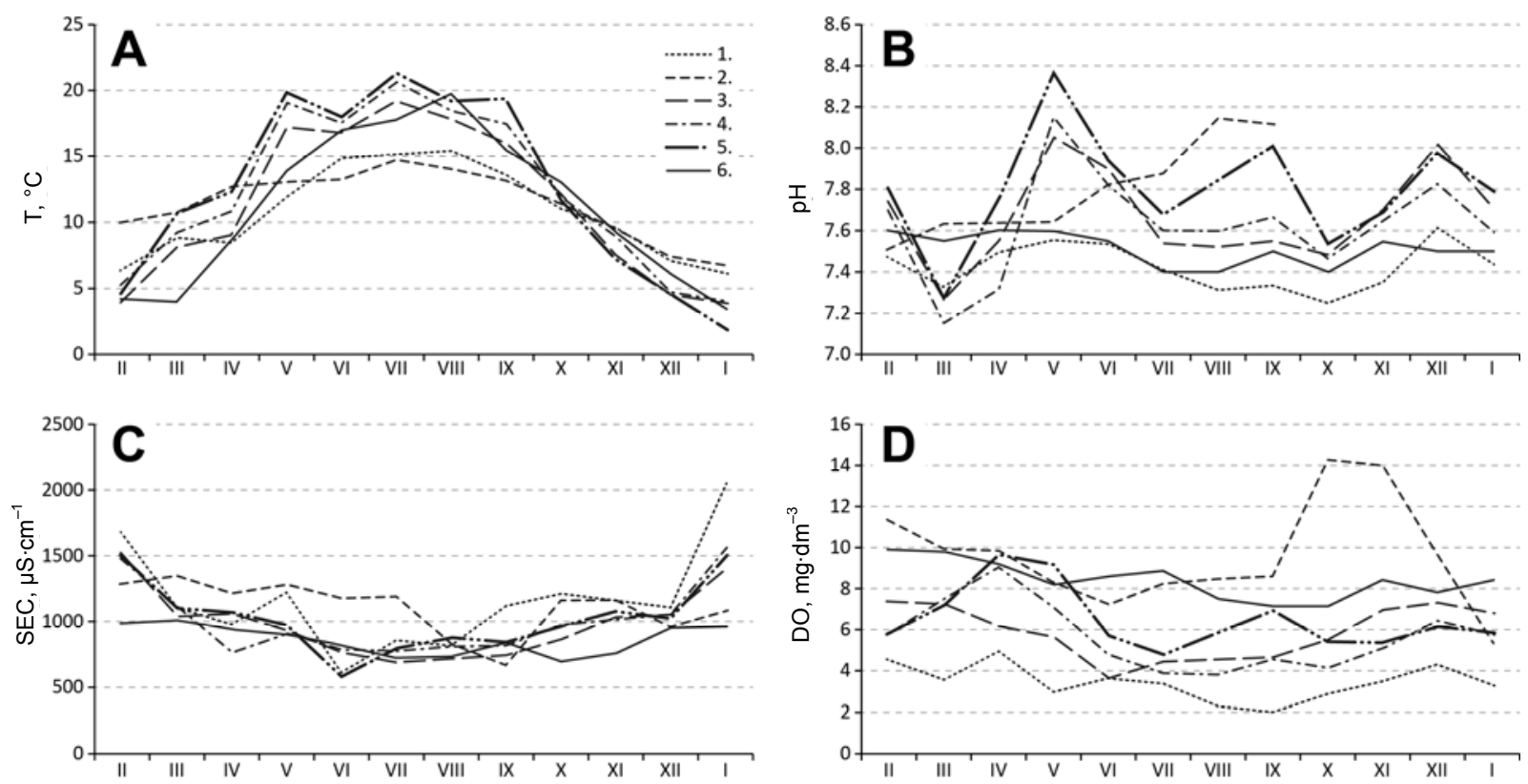

Fig. 2. Seasonal variations of selected physical and chemical water parameters at the measurement points along the Jasien River watercourse in the years 2012-2013 (points 1,3-6) and in the years 2014-2015 (point 2); A - water temperature, $\mathrm{B}-\mathrm{pH}, \mathrm{C}$ - specific conductivity, D - dissolved oxygen; source: own elaboration

during winter road maintenance procedures (Fig. 2C). The highest and most variable conductivity was recorded for the upper section of the river (point 1). Mean conductivity at this point was $1156 \mu \mathrm{S} \cdot \mathrm{cm}^{-1}$, while for point 3 is was on average by $173 \mu \mathrm{S} \cdot \mathrm{cm}^{-1}$ lower. Contamination reduction was substantially affected by biological processes occurring in the ponds dividing the two points. In the winter, water conductivity decreased along this section by $7 \%$, and in the summer by nearly $24 \%$. A similar pattern was reported for water turbidity. Apart from its considerable increase in the winter, irregular spikes were also observed in the summer months due to individual rainfall events. Mechanical effect of the ponds on turbidity reduction at point 3 was also perceived here, but while in the summer (May-August) the amount of suspended solids decreased by maximum two times, in the winter is was reduced by six to thirty times.

Biological processes occurring in the reservoirs resulted in significant reduction of nitrate nitrogen concentration between both sections (upstream and downstream of point 2 - the place of the probe installation). Average content of nitrate nitrogen was reduced between these points from 2.35 to 1.40 $\mathrm{mg} \cdot \mathrm{dm}^{-3}$, and the difference between the extremes from 4.0 to $2.0 \mathrm{mg} \cdot \mathrm{dm}^{-3}$. Maximum concentration of nitrate nitrogen was reported in the spring (MarchMay), when water plants that absorb nitrogen started to grow. At point 1, representing upper part of the catchment without any reservoirs, average concentration of nitrate nitrogen in the summer half of the year was higher than in the winter by as much as 0.3 $\mathrm{mg} \cdot \mathrm{dm}^{-3}(14 \%)$. At point 3 , it decreased due to the pond-related effects by $0.1 \mathrm{mg} \cdot \mathrm{dm}^{-3}(-7 \%)$ compared to the winter season.
$\mathrm{pH}$ of the Jasien River water was slightly alkaline due to considerable contamination with household sewage (Fig. 2B). At the upper part of the catchment (point 1), average $\mathrm{pH}$ was 7.4 and showed the lowest annual variation. At point 3 , located downstream of numerous wastewater collecting pipes of storm water and combined sewage system, $\mathrm{pH}$ was higher by on average 0.2 and its dispersion increased. Annual pattern of $\mathrm{pH}$ changes clearly showed two distinct periods of high basicity (December and May), and a minimum occurring in March. The last process was probably caused by a supply of melt water of $\mathrm{pH}$ close to neutral. Pond water might still be alkaline then as average annual $\mathrm{pH}$ was 8.33 for the pond at point 1 and 8.5 for the one at point 2 [STOLARSKA, FRĄTCZAK 2005].

Concentration of dissolved oxygen depends to some extent on water temperature but the difference in its average value between the winter and summer season in the upper section of the watercourse (point 1-point 3) was only 5-7\% (Fig. 2D). Oxygen concentration increased down the river when the contaminated water was diluted with rain water or oxygenated by flowing quickly in a concrete channel. Its maximum concentration was recorded at the turn of March and April and minimum in the autumn.

Directing the water from draining the Łódź Fabryczna station to the Jasien River changed stable hydrological, physical and chemical regime of the river. The greatest amount of water $\left(0.503 \mathrm{~m}^{3} \cdot \mathrm{s}^{-1}\right)$ was discharged from the construction site between January 2014 and February 2015, at the beginning of the recording period (between late January and early February). Then, it gradually decreased but in the end an average daily discharge still exceeded $0.2 \mathrm{~m}^{3} \cdot \mathrm{s}^{-1}$ (Fig. $3 \mathrm{G})$. The first phase of the works required establish- 

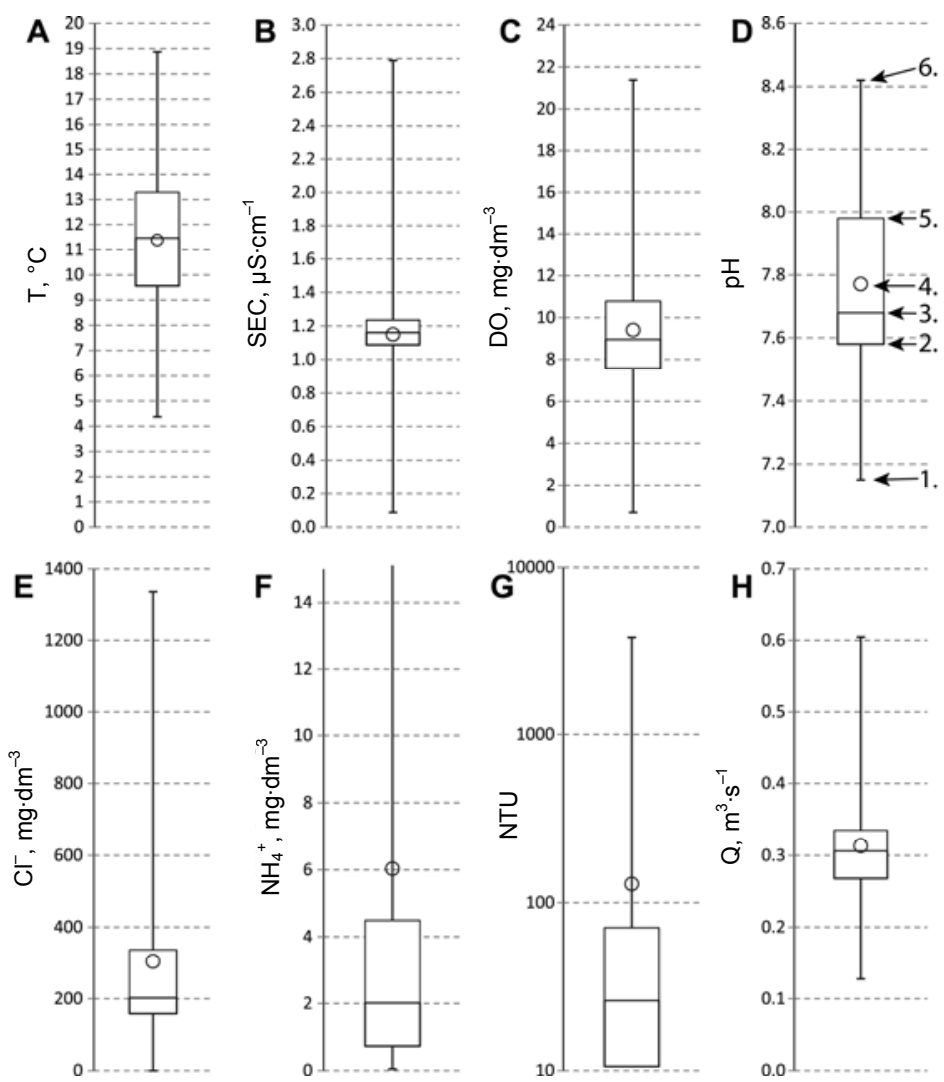

Fig. 3. The basic statistical characteristics of 15-minute Jasień River physical and chemical water parameters during the period Feb. 2014Jan. 2015 (point 2): A - water temperature; B - specific conductivity;

$\mathrm{C}$ - dissolved oxygen; $\mathrm{D}-\mathrm{pH}$; $\mathrm{E}$ - the concentration of chlorides;

$\mathrm{F}$ - the concentration of ammonium; $\mathrm{G}$ - water turbidity; $\mathrm{H}$ - the amount of water discharged from the drainage area to the Jasien River (daily average obtained from the Łódź city hall); statistical parameters:

$1=$ minimum, 2 = lower quartile, $3=$ median, $4=$ average, $5=$ upper quartile, $6=$ maximum; source: own study

ing a cone of depression covering the excavation area. Its range had to be maintained in the second phase. As a consequence, average monthly flows exceeded the Jasien River flow in its upper section $\left(0.044 \mathrm{~m}^{3} \cdot \mathrm{s}^{-1}\right)$ by six times, and at the beginning by even ten times. Due to increased flow, water residence time in the flow-through reservoirs shortened dramatically from the original three weeks to only three to four days, and considering the fact that the Przędzalniana reservoir was filled up to only one third of its standard capacity, this time was even shorter than one day.

A comparison of the results from point 1 and 2 (probe) - Figure 2A revealed that shortening the time of flow through the system of ponds reduced the amplitude of temperature fluctuations from 9.2 to $8.0^{\circ} \mathrm{C}$. This was accompanied by an increase in average annual water temperature from 10.3 to $12.1^{\circ} \mathrm{C}$. This change was the most pronounced for average temperature of the winter season that rose from 7.8 to $9.5^{\circ} \mathrm{C}$. Monthly minimum was also elevated from 6.2 to $6.8^{\circ} \mathrm{C}$ (January), while average water temperature in the summer season decreased by $0.4^{\circ} \mathrm{C}$.
Flattening was also observed for the annual pattern of conductivity and $\mathrm{pH}$ (Fig. 2B, 2C). The amplitude of conductivity was significantly reduced from 1425 to $686 \mu \mathrm{S} \cdot \mathrm{cm}^{-1}$, and its annual average dropped by $44 \mu \mathrm{S} \cdot \mathrm{cm}^{-1}(4 \%)$. Desalinization caused by melt water in the spring was no longer observed in the Jasień River - conductivity values decreased only during summer rainfalls in August and September. The water became more alkaline, as mean $\mathrm{pH}$ in the investigated months of the years 2012-2013 and 2014-2015 (February-September) changed from 7.4 to 7.7. Over time, a visible shift in average monthly $\mathrm{pH}$ was observed from 7.5 in February to 8.1 in September 2014. It was caused by pumping out deeper and more alkaline water that was in direct contact with carbonate saturated till. This also affected the pattern of chloride concentration that was less dependent on winter road maintenance and increased from April (minimum amount of melt water $\left.83 \mathrm{mg} \mathrm{Cl} \cdot \mathrm{dm}^{-3}\right)$ through November $(1038$ $\mathrm{mg} \mathrm{Cl} \cdot \mathrm{dm}^{-3}$ ).

Intense movement of water in the channel resulted in a relatively high average concentration of dissolved oxygen $\left(9.6 \mathrm{mg} \mathrm{O}_{2} \cdot \mathrm{dm}^{-3}-85 \%\right)$ - Figure 2D. Due to lower temperature amplitude, the difference in oxygen concentration between the summer $\left(9.2 \mathrm{mg} \mathrm{O}_{2} \cdot \mathrm{dm}^{-3}-82 \%\right)$ and winter $\left(11.0 \mathrm{mg} \mathrm{O} \mathrm{O}_{2} \cdot \mathrm{dm}^{-3}-97 \%\right)$ seasons was small. The highest concentration of oxygen was recorded in October and November $\left(14.1 \mathrm{mg} \mathrm{O}_{2} \cdot \mathrm{dm}^{-3}\right)$ when water saturation exceeded $120 \%$. Oversaturation with oxygen may often happen when water temperature increases sharply [DOJLIDO 1995]. In this study, it was probably caused by mixing warm water drained from the construction site with relatively cold surface water highly saturated with gases. This phenomenon negatively affects water biocenosis. Oxygen oversaturation could also be increased by algae [NOVOTNY, ZHENG 1989], as a large accumulation of filamentous algae was observed in autumn 2014 upstream of Przędzalniana reservoir in an open section of the channel. Their intense growth was probably facilitated by higher water temperature than typical for this season. During the day, phytoplankton gave off huge amounts of oxygen further increasing temperaturemediated water oversaturation.

Since commencing the drainage works, water turbidity increased on average from 22 to 44 NTU. As the reservoir at Przędzalniana street was partly filled and could not operate as a sedimentation reservoir for suspended matter transported by the river, a substantial growth in water turbidity (220-400 NTU) was recorded during summer floods (July-August). It was 
not caused by water discharge from the construction site but the suspended solids might come from an exposed and poorly reinforced reservoir basin. The summer season was also characterized by high concentration of ammonium cations (on average $5.13 \mathrm{mg}$ $\mathrm{NH}_{4}^{+} \cdot \mathrm{dm}^{-3}$ ), four times higher than in the winter. This was probably due to fertilization in the agricultural part of the catchment and the dominance of ammonium forms of nitrogen in the first half of the growing season [PIETRZAK 2014; WIVUTVONGVANA, JIRAPORNCHAROEN 2002].

The observation series of selected physical and chemical parameters measured every 15 minutes included over $35 \mathrm{k}$ of records ( $\mathrm{pH}$ and $\mathrm{NH}_{4}{ }^{+}$ca. $24.5 \mathrm{k}$ ). Their variation in the recording period is well illustrated by box and whisker graphs (Fig. 3). The presented characteristics involve the entire observation series. Therefore, they cannot be directly compared with the results of measurements conducted every two weeks. However, they clearly show the scale of variability in individual physical and chemical parameters during the drainage period. Strong asymmetry of distribution is easy to spot for some parameters $\left(\mathrm{Cl}^{-}\right.$, $\mathrm{NH}_{4}{ }^{+}, \mathrm{NTU}$ ), indicating occasional high values very different from the average ones. They were usually related to floods, both in the summer and in the winter. Some examples with an analysis of their course are discussed below.

The pattern of some physical and chemical properties, expressed by means of the series of absolute values and their changes recorded daily, is often characterized by synchronicity and asynchronicity. The strength of correlations was tested using linear Pearson correlation coefficient that for some of the series proved to be statistically significant at the level of $5 \%$. An example could be a correlation between the concentration of chloride and water temperature. It was not due to increased solubility of chlorides with increasing water temperature but to the use of salt in winter road maintenance. Thus, the correlation coefficient of daily changes in chloride concentration and water temperature was negative $(r=-0.53)$. The use of chlorides obviously affected daily pattern of water conductivity but the correlation coefficient was very low $(r=0.20)$. The day-to-day changes were slightly more synchronic in the case of chloride concentration and water $\mathrm{pH}(r=0.25)$, reaching even moderate level $(r=0.55)$ for absolute values. This was caused by the fact that chlorides increase water conductance while sodium and potassium increase its basicity.

Some of the investigated physical and chemical parameters strongly correlated with the amount of water discharged from the construction site. Positive correlation was found for average daily flow rate of the discharged water and conductivity of the Jasien River water $(r=0.52)$ and concentration of dissolved oxygen $(r=0.61)$. Negative correlation was computed for the concentration of chlorides $(r=-0.58)$ and water temperature $(r=-0.67)$ and $\mathrm{pH}(r=-0.18)$. During the study, the amount of water discharged into the
Jasień River decreased and it was also gradually diluted with rainwater. Increased water temperature was associated with decreasing oxygen concentration and it was further enhanced by pumping water out of deeper and more alkaline groundwater horizons. Elevated water temperature and reduced flow rate resulted also in increased concentration of ammonium ions $(r=0.64)$. Turbidity most strongly correlated with flow rate $(r=0.19)$ and this was mostly due to high NTU during floods.

Seasonal changes in physical and chemical parameters are accompanied by circadian rhythms. Their direction may depend on current weather conditions, particularly flood causing rainfall or snowmelt [BARTNIK, MONIEWSKI 2010]. Such a flood happened after continuous rainfall recorded on $27^{\text {th }}$ and $28^{\text {th }}$ May 2014 (Fig. 4). The rainfall height was $7.7 \mathrm{~mm}$ and maximum intensity was $0.8 \mathrm{~mm}$ per $15 \mathrm{~min}$. The presence of rainwater necessitated greater discharge from the railway construction site. A drop in air temperature and a supply of colder water (also from the catchment) resulted in a drop of the Jasien River water temperature by $3.4^{\circ} \mathrm{C}$. This was accompanied by a decrease in conductivity by over $400 \mu \mathrm{S} \cdot \mathrm{cm}^{-1}$, and a rise in oxygen concentration by $2 \mathrm{mg} \cdot \mathrm{dm}^{-3}$ and $\mathrm{pH}$ by 0.3 . Both chloride and ammonium concentrations were reduced by $25 \%$ and $64 \%$, respectively. Water turbidity was reduced by $95 \%$, which was unexpected, as such situations are often associated with its increase. In this case, most of the suspended solids were captured by the flow-through reservoirs. Slight rainfall intensity resulted in small direct runoff and the water slowly running over the surface did not exert considerable erosion strength. The runoff concerned the areas directly adjacent to riverbeds activated at almost any rainfall event and therefore well established.

The flood caused by intense rains between 30 August and 2 September 2014 had a slightly different course. The rainfalls came in a few stages and their maximum intensity was $3 \mathrm{~mm}$ per $15 \mathrm{~min}$ (Fig. 5). Most of the investigated physical and chemical parameters were clearly related to the changes in daily water temperature. When it rose in the afternoon, $\mathrm{pH}$ also rose by 0.2 and oxygen concentration increased by $2.5 \mathrm{mg} \cdot \mathrm{dm}^{-3}$, while chloride and ammonium ions concentration decreased by $13 \%$ and $17 \%$, respectively. These changes were probably associated with oxygen production by water plants that by the end of the summer were well developed and might absorb significant amounts of dissolved substances. Changes in conductivity closely correlated with each supply of rainwater. However, the most important difference when comparing this flood with the one triggered by continuous rainfall was the initial drop in conductivity by about $200 \mu \mathrm{S} \cdot \mathrm{cm}^{-1}$ followed by its sharp increase by about $400 \mu \mathrm{S} \cdot \mathrm{cm}^{-1}$. Also in this case, the water that first reached the measuring point was relatively clear as it came from often washed areas in the nearest vicinity of riverbeds. After some time, when the rainfall 

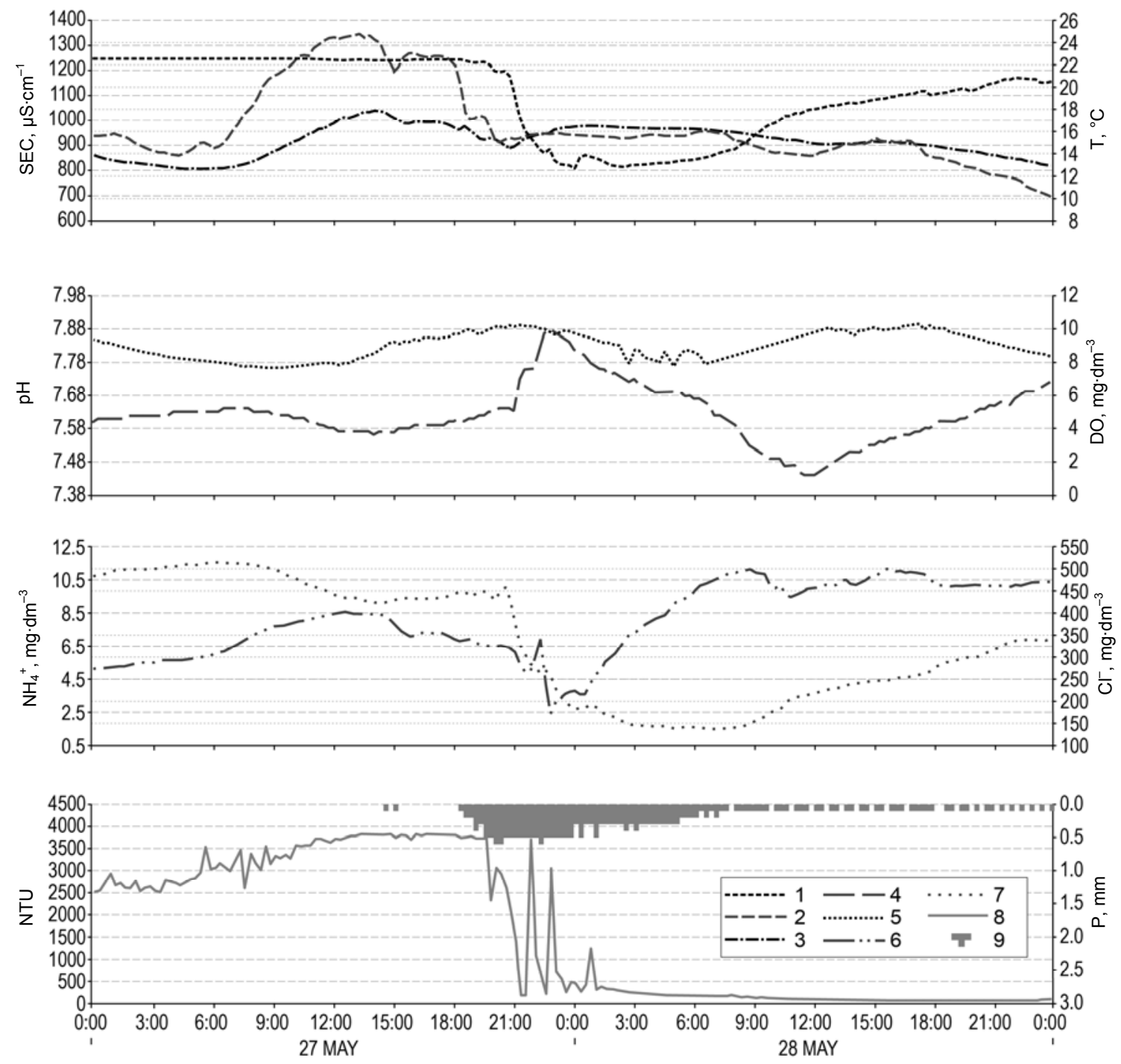

Fig. 4. The variability of selected physical and chemical water parameters of Jasien River recorded for a 15-minute time step at point 2 during the flood caused by extensive rainfall in the period 27-28 May 2014; $1=$ specific conductivity, $2=$ air temperature, $3=$ water temperature, $4=\mathrm{pH}, 5=$ dissolved oxygen, $6=$ the concentration of ammonium, $7=$ the concentration of chlorides, $8=$ water turbidity, $9=$ precipitations; source: own study

intensity increased, a rapid flow of suspended solids was recorded that were put into motion by strong surface runoff in the areas of the catchment not located in the immediate vicinity of the riverbeds. This was reflected in the dynamics of NTU changes that depended on rainfall intensity. Another factor that might be important in such situations was flushing storm drains that are usually blocked by rubbish and generate relatively clean water. Only huge amount of water supplied during intense rainfall is capable of moving the accumulated sediments.

Different sequence of events was observed during a flood triggered by snow melt between 2 and 3 February 2014 (Fig. 6). During this type of events, there is no supply of rainwater or the rainfalls do not significantly affect the flood course. Duration and scope of such a flood depend on air temperature, and particularly on the temperatures above $0^{\circ} \mathrm{C}$. In this case, air temperature was only $1.8^{\circ} \mathrm{C}$ while water temperature, strongly influenced by the temperature of the discharged water, was only $0.8^{\circ} \mathrm{C}$. Although the Jasien was dominated by groundwater, changes in the other physical and chemical parameters were visible but delayed in relation to air temperature by about eight hours. The reason for this is a long time it takes the cold air to affect cooled area of the urban catchment and snow cover and a complicated route by which the melt water reaches the measuring point. Increase in water conductivity (by $145 \mu \mathrm{S} \cdot \mathrm{cm}^{-1}$ ) was followed by rising concentration of chlorides (by 115 $\mathrm{mg} \cdot \mathrm{dm}^{-3}$, i.e. $91 \%$ ) and ammonium (by $0.34 \mathrm{mg} \cdot \mathrm{dm}^{-3}$, i.e. $37 \%$ ), and only slight changes in $\mathrm{pH}$ (by 0.06 ) and oxygen concentration. This was due to mobilization of contaminants infiltrating the snow cover or supplied from the roads, as confirmed by a simultaneous increase in water turbidity. 

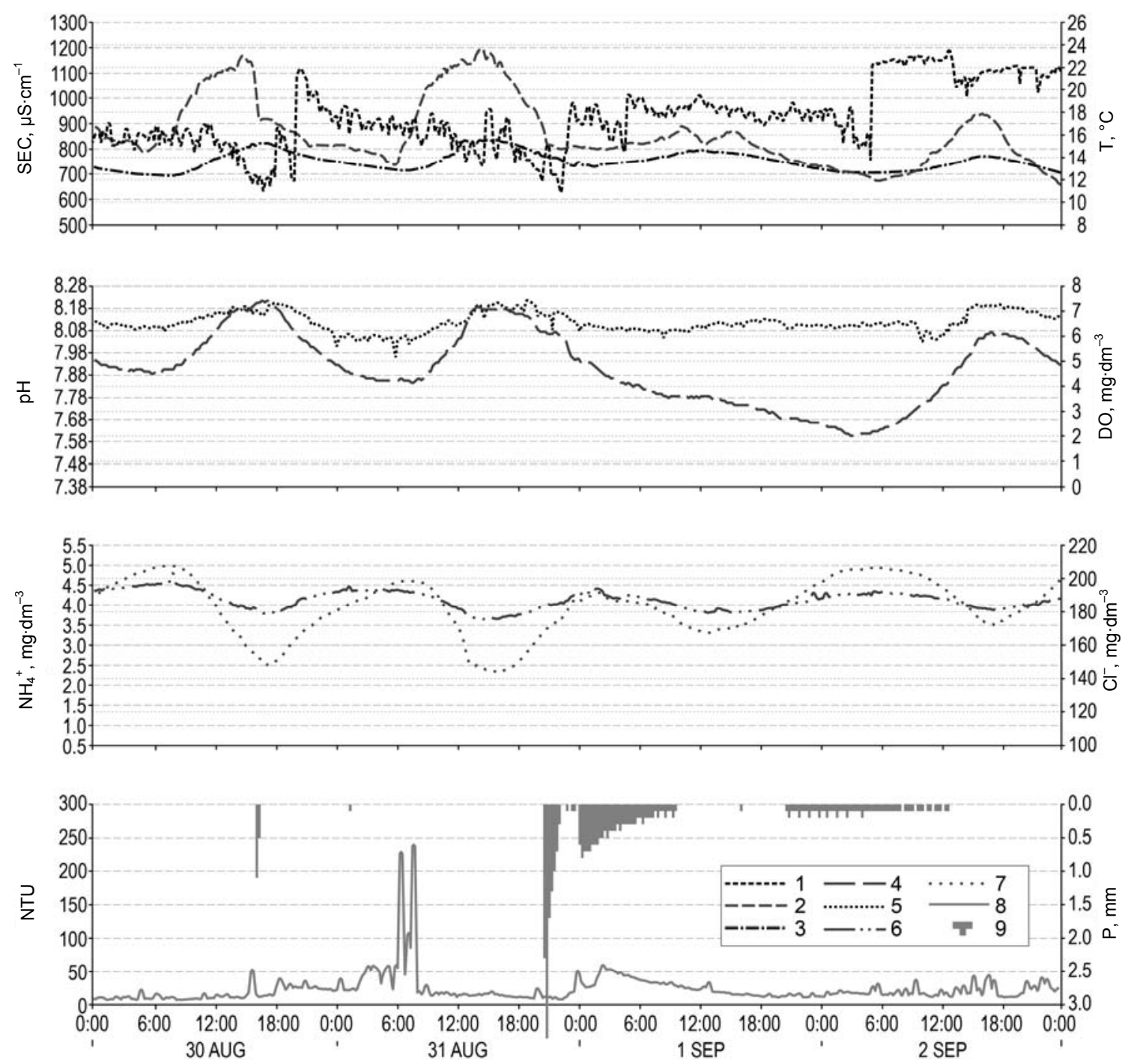

Fig. 5. The variability of selected physical and chemical water parameters of Jasień River recorded for a 15-minute time step at point 2 during the flood caused by intense rains between 30 August and 2 September 2014; the changes of air temperature and precipitation were recorded at the PKP-Cargo automatic weather station; $1-9$ as on Figure 4;

source: own study

A comparison of these three types of flood showed that, despite occurring at different times of the year, they were all to some extent affected by the water discharged from the construction site. For example, average water temperature during snowmelt flood was by $9.2^{\circ} \mathrm{C}$ higher than air temperature, while in the summer season floods it was by $1.3-3.5^{\circ} \mathrm{C}$ lower (Tab. 2). This was to great extent due to temperature stabilization by the supply of groundwater discharged from the construction site. Moreover, the snowmelt flood was characterized by the highest av- erage conductivity and the highest chloride concentration. Due to considerable share of water from melted snow cover, the Jasien River water was characterized by good oxygenation, neutral $\mathrm{pH}$, low ammonium concentration and low turbidity. In the summer season, affected by the processes occurring in the flowthrough reservoirs, the floods were associated with lower conductivity, lower oxygenation of the water, its slightly alkaline nature, elevated levels of ammonium, and higher turbidity. 

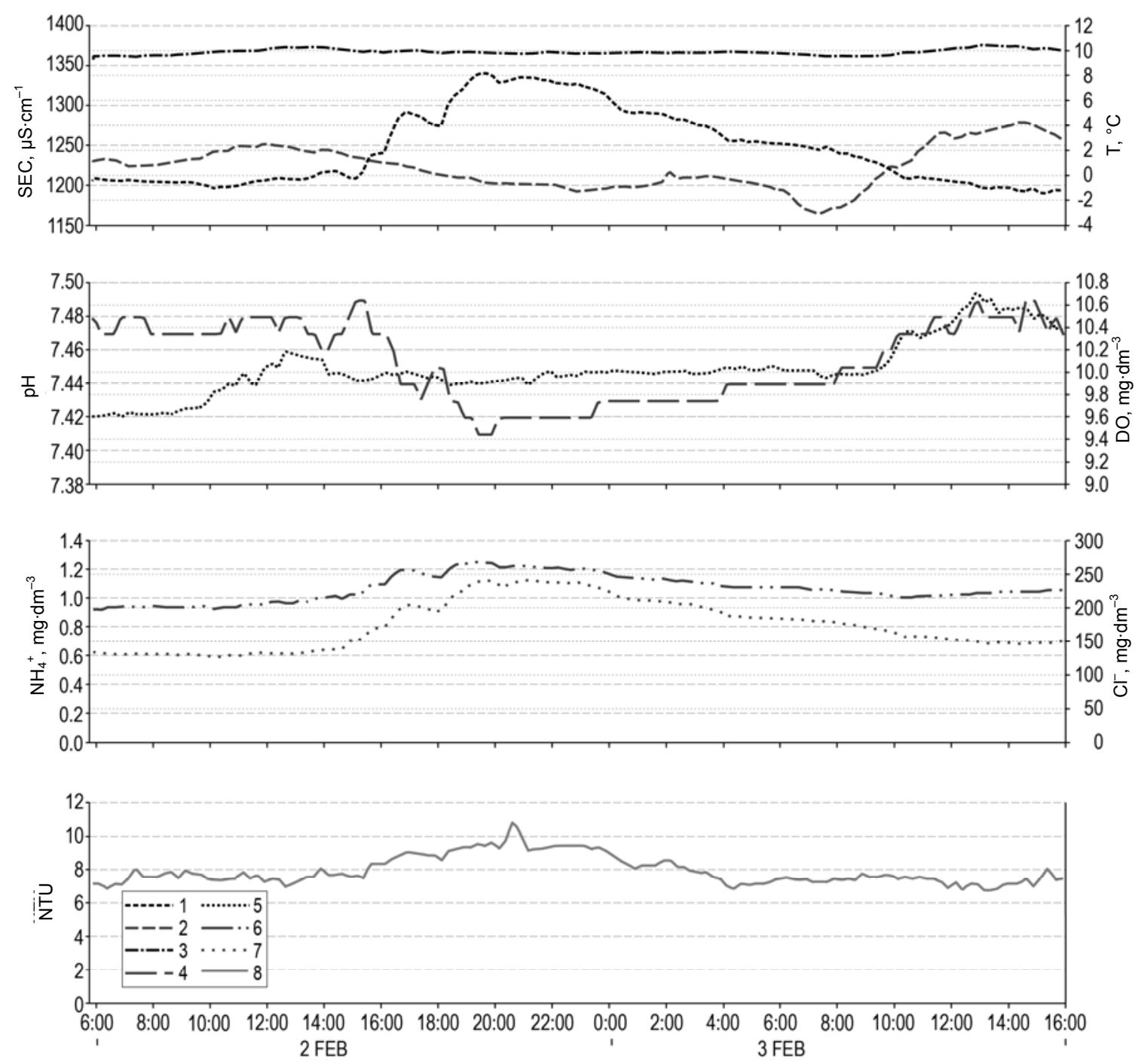

Fig. 6. The variability of selected physical and chemical water parameters of Jasień River recorded for a 15-minute time step at point 2 during the flood caused by snowmelt in the period 2-3 of Feb 2014; 1-9 as on Figure 4; source: own study

Table 2. The average water quality characteristics of the Jasień River recorded by the YSI probe during chosen raised-water stages in the investigated period

\begin{tabular}{|c|c|c|c|c|c|c|c|c|c|}
\hline \multirow{2}{*}{ Date } & \multirow{2}{*}{ Type $^{1)}$} & \multirow{2}{*}{$\begin{array}{l}\text { Temperature } \\
{ }^{\circ} \mathrm{C}\end{array}$} & \multirow{2}{*}{$\begin{array}{c}\text { SEC } \\
\mu \mathrm{S} \cdot \mathrm{cm}^{-1}\end{array}$} & \multicolumn{2}{|c|}{ Dissolved oxygen } & \multirow{2}{*}{$\mathrm{pH}$} & \multirow{2}{*}{$\begin{array}{c}\mathrm{Cl}^{-} \\
\mathrm{mg} \cdot \mathrm{dm}^{-3}\end{array}$} & \multirow{2}{*}{$\begin{array}{l}\mathrm{NH}_{4}^{+} \\
\mathrm{mg} \cdot \mathrm{dm}^{-3}\end{array}$} & \multirow{2}{*}{ NTU } \\
\hline & & & & $\mathrm{mg} \cdot \mathrm{dm}^{-3}$ & $\%$ & & & & \\
\hline 2-3 Feb. 2014 & SM & 9.9 & 1234.0 & 9.98 & 88.6 & 7.46 & 242 & 1.06 & 7.6 \\
\hline 27-28 May 2014 & ER & 15.1 & 1149.0 & 9.05 & 80.7 & 7.62 & 181 & 8.12 & 353.0 \\
\hline 30 Aug.-2 Sep. 2014 & RS & 13.7 & 909.9 & 6.51 & 58.1 & 7.91 & 229 & 4.17 & 19.5 \\
\hline
\end{tabular}

${ }^{1)}$ Raised-water stage type: $\mathrm{SM}=$ snowmelt, $\mathrm{ER}=$ extensive-rainwater, $\mathrm{RS}=$ intense-rainwater.

Explanations: $\mathrm{SEC}=$ specific conductivity; $\mathrm{Cl}^{-}=$the concentration of chlorides; $\mathrm{NH}_{4}{ }^{+}=$the concentration of ammonium; $\mathrm{NTU}=$ nephelometric turbidity units.

Source: own elaboration.

\section{CONCLUSIONS}

The study of the drained water influence on the small urban river regime was the aim of the research. Discharging water from the construction site to the Jasień River significantly affected physical and chemical parameters of the river water. Increased runoff resulted in shortened water residence time in the flowthrough reservoirs and the entire investigated hydrological system. Average annual water temperature increased and a decrease in its amplitude was observed. The annual conductivity and $\mathrm{pH}$ patterns became more uniform and the changes in $\mathrm{pH}$ followed a clear trend of monthly changes. Water turbidity increased by two times and during summer floods this parameter was often even a few times higher than before the drainage commenced.

Chloride concentration was systematically growing over the study period. This growth and higher water $\mathrm{pH}$ were probably associated with increasing level 
of contaminants in the discharged water and its gradually decreasing uptake. The correlation was particularly visible $(r=0.55)$ when changes in these parameters were analyzed on day-to-day basis. Chlorides improved water conductance and sodium and potassium increased basicity.

The amount of water discharged from the construction site of Łódź Fabryczna railway station affected the course of floods irrespective of the time of the year. However, this effect was highly variable. The strongest correlation was found between the amount of water discharged from the construction site and concentration of dissolved oxygen and conductivity (positive), and chloride concentration, water temperature and $\mathrm{pH}$ (negative).

The changes reported in this study are so interesting that the observations will be continued until the engineering works are finished. The future investigations should concern the character of the changes of hydrochemical regime of the Jasien River. Although the results of this study are case-specific, the overall conceptual approach and methodologies applied may be directly transferred to other urban areas.

\section{REFERENCES}

BARTNIK A., MONIEWSKI P. 2010. Formowanie się i charakter wezbrań dwu małych rzek o różnym stopniu zurbanizowania zlewni na przykładzie Sokołówki i Dzierżąznej. W: Obszary metropolitalne we współczesnym środowisku geograficznym [Developing and character of floods in two small rivers with different degrees of urbanization. Sokołówka and Dzierżązna catchments case. In: Metropolitan areas in the modern geographical environment]. T. 2. Ed. M. Barwiński. 58. Zjazd Polskiego Towarzystwa Geograficznego. T. 2. Łodź. 08.0912.09.2010 r. Oddz. Łódzki PTG, Wydz. Nauk Geogr. UŁ p. 325-336.

BARTNIK A., MONIEWSKI P. 2015. Zmiany jakości łódzkiego Jasienia w wyniku głębokiego odwodnienia terenu w związku z budową dworca kolejowego Łódź-Fabryczna. W: Nowoczesne metody i rozwiązania w hydrologii i gospodarce wodnej [Changes in water quality of Jasień River as a result of deep drainage of the construction area of the Łódź-Fabryczna railway station. In: Modern methods and solutions in hydrology and water management]. Eds. D. Absalon, M. Matysik, M. Ruman. Monografie Komisji Hydrologicznej PTG. T. 3 Sosnowiec. PTG p. 59-73.

Cashman P.M., Preene M. 2013. Groundwater lowering in construction. A practical guide to dewatering. Applied Geotechnics, 6. Boca Raton. CRC Press, Taylor and Francis Group p. 645.

DoBRZYŃSKA A. 2013. Sezonowe zmiany wybranych parametrów fizyko-chemicznych wód rzeki Jasień w Łodzi [Seasonal changes of selected physicochemical parameters of the Jasien River waters]. Typescript. Łódź. Uniwersytet Łódzki, Katedra Hydrologii i Gospodarki Wodnej pp. 69.

DoJLIDO J.R. 1995. Chemia wód powierzchniowych [Chemistry of surface waters]. Białystok. Ekonomia i Środowisko. ISBN 83-85792-22-8 pp. 342.

EPting J., HugGenberger P., RAUBer M. 2008. Integrated methods and scenario development for urban groundwa- ter management and protection during tunnel road construction: A case study of urban hydrogeology in the city of Basel, Switzerland. Hydrogeology Journal. Vol. 16. Iss. 3 p. $575-591$.

PIETRZAK S. 2014. Kształtowanie się ilości azotu mineralnego w mineralnych glebach łakowych w Polsce w latach 2008-2012 [The amount of inorganic nitrogen in mineral meadow soils in Poland in the years 20082012]. Woda-Środowisko-Obszary Wiejskie. T. 14. Z. 3(47) p. 113-124.

Powers J.P., Corwin A.B., Schmall P.C., KAeCK W.E. 2007. Construction dewatering and groundwater control. New methods and applications. $3^{\text {rd }}$ ed. Hoboken, New Jersey. John Wiley and Sons. ISBN 978-0-47147943-7 pp. 656.

QIN H.P., SU Q., Khu S.T., TANG N. 2014. Water quality changes during rapid urbanization in the Shenzhen River Catchment: An integrated view of socio-economic and infrastructure development. Sustainability. Vol. 6 p. 7433-7451. DOI:10.3390/su6107433.

NovotNY V., ZHENG S. 1989. Impact of nonpoint pollution on a Great Lakes freshwater harbor-estuary. In: Urban discharges and receiving water quality impacts. Ed. J.B. Ellis. Advances in Water Pollution Control. A series of conferences sponsored by IAWPRC. Oxford. Pergamon Press p. 27-36.

StOlarsKa M., FrątCZAK J. 2005. Sezonowa zmienność podstawowych właściwości fizykochemicznych w wybranych stawach Łodzi. W: Jeziora i sztuczne zbiorniki wodne [Seasonal variability of basic physicochemical properties of water in selected ponds of Łodź. In: Lakes and artificial water reservoirs - natural processes and socio-economic importance]. Eds. A.T. Jankowski, M. Rzętała. Sosnowiec. UŚ p. 221-231.

TUlaram G.A., DoBOS J. 2005. Changes in subsurface water quality during coastal canal estate constructions. Australian Geomechanics Journal. Vol. 40. Iss. 3 p. 85-94.

VishnuRADHAN R., Zainudin Z., SREeKanth G.B., DHIMAN R., SALleh M.N., Vethamony P. 2015. Temporal water quality response in an urban river: A case study in peninsular Malaysia. Applied Water Science. July p. 1-11. DOI: $10.1007 / \mathrm{s} 13201-015-0303-1$

WIOŚ 2010-2013. Sprawozdania $\mathrm{z}$ monitoringu regionalnego zwykłych wód podziemnych na terenie województwa lódzkiego w latach 2010-2013 [Reports from regional monitoring of groundwater in the Łódź Voivodeship in 2010-2013] [online]. Łódź [Access 04.01.2016]. Available at: http://www.wios.lodz.pl/ Sprawozdania_z_monitoringu_regionalnego_zwyklych wod_podziemnych, 160

WivutVOngVAna P., JiRAPORNCharoen S. 2002. Seasonal changes in soil ammonium and nitrate in relation to crop production. Chiang Mai University Journal of Natural of Sciences. Vol. 1(3) p. 245-256.

YE X.W., RAN L., YI T.H., Dong X.B. 2012. Intelligent risk assessment for dewatering of metro-tunnel deep excavations. Mathematical Problems in Engineering. Vol. 2012 p. 1-13 DOI: 10.1155/2012/618979.

YSI undated. YSI 6820 and 6920 V2 Sondes. Specifications document \#E36. Yellow Springs pp. 2.

Yu K., ZhaO M., Lv B., Li Z. 2011. Research of the environmental impact assessment methods caused by foundation pit dewatering. Paper presented at the ISWREP 2011 - Proceedings of 2011 International Symposium on Water Resource and Environmental Protection. Vol. 4 p. 2777-2780. DOI: 10.1109/ISWREP.2011.5893 455 . 


\section{Adam BARTNIK, Piotr MONIEWSKI}

\section{Zmiany jakości wód małej rzeki miejskiej pod wpływem glębokiego odwodnienia terenu budowy}

\section{STRESZCZENIE}

Wody Jasienia od niedawna znajdują się pod wpływem odwodnienia terenu budowy podziemnego dworca Łódź Fabryczna. Rzeka Jasień jeszcze ćwierć wieku temu była odbiornikiem ścieków z łódzkich fabryk włókienniczych. Zrzut z odwodnienia wykopu budowy podziemnego dworca Łódź Fabryczna został skierowany w styczniu 2014 r. do koryta Jasienia i zmienił stabilny reżim hydrologiczny i fizykochemiczny tej niewielkiej rzeki. W jego efekcie średnie miesięczne przepływy w górnym biegu Jasienia zwiększyły się sześciokrotnie, a początkowo nawet 10-krotnie. Stężenie chlorków systematycznie zwiększało się w okresie badań. To zwiększenie, a także zwiększenie zasadowości wody były prawdopodobnie związane ze zwiększeniem zanieczyszczenia wód odpompowywanych z wykopu. Wzrosła także średnia roczna temperatura wody, a jednocześnie zmniejszyła się jej amplituda. Roczne przebiegi przewodności elektrycznej właściwej i odczynu wody uległy wyrównaniu, a zmienność odczynu wynikała $\mathrm{z}$ wyraźnego trendu zmian miesięcznych. Mętność wody zwiększała się dwukrotnie w ciagu roku, zaś podczas letnich wezbrań okazywała się często nawet większa niż przed rozpoczęciem odwadniania. Chlorki zwiększyły przewodność elektryczną właściwą wody, a obecność jonów sodu i potasu spowodowała zwiększenie zasadowości wody. Zaobserwowane zmiany rodzą pytania o trwałość reżimu hydrochemicznego Jasienia po zakończeniu budowy dworca.

Słowa kluczowe: hydrologia miejska, jakość wody, jakość ścieków deszczowych, oddziaływanie środowiska, rewitalizacja, zagospodarowanie terenu 